\title{
THE ROLE OF STUDENTS' LIFE COURSE CONCEPTION IN THEIR SELF-DEVELOPMENT
}

\begin{tabular}{|c|c|}
\hline \multicolumn{2}{|c|}{$\begin{array}{l}\text { Dr. Natalia Lyz, Southern Federal University, Russian Federation, } \\
\text { E-mail: nlyz@sfedu.ru } \\
\text { Dr. Amina Prima, WIS Software, Rostov-on-Don, Russian Federation, } \\
\text { E-mail: amina.prima@gmail.com } \\
\text { Dr. Anna Opryshko, Southern Federal University, Russian Federation, } \\
\text { E-mail: opranna@yandex.ru }\end{array}$} \\
\hline AR T I C LE INFO & $\begin{array}{l}\text { A B S T R A C T } \\
\text { To facilitate students' self-development it is necessary to understand the }\end{array}$ \\
\hline Original Research & inner factors of this process as well as the ways of increasing its productivity. \\
\hline Received: January, 15.2020. & This paper studies whether a person's idea (mental representations) of their \\
\hline Revised: February, 17.2020. & own life course influences self-development. To examine this phenomenon \\
\hline $\begin{array}{l}\text { Accepted: February, } 29.2020 . \\
\text { doi: } 10.5937 / \text { IJCRSEE2001037L }\end{array}$ & $\begin{array}{l}215 \text { engineering students completed the study. The empirical research } \\
\text { included two phases. The purpose of the first phase was to examine if there } \\
\text { was co-herence of the two analyzed constructs - the life course conception }\end{array}$ \\
\hline UDK & and in-tentional self-development. During the second phase a programme \\
\hline $159.947 .5 .072-057.875$ & $\begin{array}{l}\text { was im-plemented which was dedicated to the improvement of students' } \\
\text { life course conception. Also, changes in indicators of self-development and }\end{array}$ \\
\hline $\begin{array}{l}\text { Keywords: } \\
\text { engineering education, } \\
\text { students, } \\
\text { intentional self-development, } \\
\text { life course conception. }\end{array}$ & $\begin{array}{l}\text { student's life course conception, awareness of experience and future goals, } \\
\text { understanding of one's significant life achievements, attitude toward oneself } \\
\text { as a source of life events and achievements, and thoughtful actions in goal } \\
\text { pursuit promote intrinsic motivation, and activity in self-development. The } \\
\text { improvement of student's life course conception and formation of meaningful } \\
\text { ideas about their own lives help to actualize self-development. 'The results } \\
\text { of the study can be implemented in education programmes' development } \\
\text { in order to choose appropriate methods for the facilitation of students' } \\
\text { self-development. }\end{array}$ \\
\hline
\end{tabular}

(C) 2020 IJCRSEE. All rights reserved.

\section{INTRODUCTION}

Ability of lifelong learning and selfdevelopment plays a major role in acquiring necessary skills of engineering students. Complexity, diversity, variability of modern world and industry, knowledge growth, and continuous technological development require permanent development and practicing of personal and professional skills by engineers. Therefore, one of the key competencies of a skillful engineer is to be able to manage intentional self-development which is understood to be a specific, inner-directed,

Corresponding Author

Dr. Natalia Lyz, Southern Federal University, Russian Federation,

E-mail: nlyz@sfedu.ru

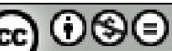

This work is licensed under a Creative Commons Attribution - NonCommercial - NoDerivs 4.0. The article is published with Open Access at www.ijcrsee.com and goal-oriented activity of a person with workable life goals, and ambitions to widen knowledge, skills, and abilities by means of self-changing and self-improvement. As Pappas and Pappas, 2011 point out that "solving complex global problems and helping students face unprecedented personal challenges and an uncertain future will require additional innovative and experimental approaches to teaching cognition and intentional self-development skills" (ibid, p.370). Along with vocational training selfdevelopment in higher education is an urgent aspect of formation of a truly professional (Mirzagitova and Akhmetov, 2015). Students' self-development is possible and is to be facilitated in educational environment (Lyz and Opryshko, 2016; Pappas and Pappas, 2011; Perez, Cromley, and Kaplan, 2014).

Taking into account an important role of personality in the process of professional growth and self-development (Kibal'chenko and Eksakusto, 2019; Lyz, 2012), it is worth noting that personal and social development 
of engineering students is complicated for several reasons: their preference of operating dehumanized models and sign systems, and gaining experience is mediated by technical means in learning. Technically based educational environment is, on the one hand, characterized by actualization of rational abilities and logical thinking of individuals, but, on the other hand, due to decreasing aspects of human perception and interaction it cannot provide a person with enough emotional expression sharing, communication (Lyz and Poznina, 2010). Such environment does not contribute to the process of self-knowledge, self-determination and self-development. In fact, psychologists point out that engineering students have significantly lower empathy than students of other subjects (Rasoal, Danielsson, and Jungert, 2012), lack social competence (Emilsson and Lilje, 2008), and generic skills (Stiwne and Jungert, 2010). In addition, in the process of self-development engineering students face challenges and barriers such as electronic over-stimulation and distraction, dysfunctional relationship with time, difficulty making intentional changes, relationship and communication difficulties, stress and tension (Pappas and Pappas, 2011). In this regard, targeted measures to foster students' selfdevelopment are essential.

In general, despite the importance of the topic of student self-development, there is not enough research specifically in enhancing self-development in engineering education. To facilitate students' self-development it is necessary to understand the essence and internal factors of this process as well as the ways of increasing its productivity. This paper intends to study this problem. With reference to existing sources on this topic below we cover the main theories of self-development and an important role of an individual in this process, consider internal factors of selfdevelopment; and point out subjective ideas of life course (named in this work as "life course conception"). The methods and results of empirical study demonstrating the role of life course conception in intentional selfdevelopment are also presented in this work.

\subsection{Intentional Self-Development: Problem Field}

It is stated that humans may play the role of agents of their own development: individuals are both the products and producers of their self-development and their motivations guide and shape it (Brandtstädter, 2009). Such phenomenon as self-development, self-cultivation, self-construction and selfimprovement are widely studied in social sciences and education. Constructivist selfdevelopment theory which blends object relations, self-psychology, and social cognition theories was developed within the scope of psychotherapy and health psychology (Stiwne and Jungert, 2010). Cultural-historical methodology and subject approach to selfdevelopment of the personality is widely used in Russian psychology. Due to this approach a person being a subject of his or her life and activity independently determines his or her goals and development vector, taking into account outer circumstances and life conditions (Abul'hanova-Slavskaya, 1991; Karpinsky, 2002; Shchukina, 2018). Such theories understood personality as an organizing, managing and directing functional center, providing self-determined (intentional) nature of self-development.

The concept of intentional selfdevelopment (ISD) is a part of positive psychology where ISD is seen as a process of personal growth in which one intentionally takes actions that are designed to shape one's self-identity and personality (Bauer, 2009). As Bauer (ibid, p.523) points out, "central to ISD are personal goals, actions, concepts of self, and the interpretive processes through which the individual comes to generate and evaluate goals, actions, and selves".

Contemporary studies of intentional self-development highlight different interpretations of this phenomenon: as a process of personal growth or as a form of self-regulation. In studying intentional selfdevelopment as a process of personal growth different researchers highlight significant points, such as: shaping one's self-identity and personality (Bauer, 2009); developing a clear and integrated sense of self and accepting oneself with a positive view (Chickering and Reisser, 1993); improving self-esteem and self-concept clarity (Yang and Brown, 2016). Researchers see intentional self-development as an important process in ensuring wellbeing (Brandtstädter, 1999), and improving both cognitive and affective abilities (Morf and Horvath, 2010). Hereby self-development can be seen as an individual development determined by inner factors. On the other hand, self-development is one of the person's activities, so it can be considered as selfregulation in which people act, reach goals, observe outcomes and adjust these goals and 
activities (Bauer, 2009; Brandtstädter, 1999; Morf and Horvath, 2010). Brandtstädter (2009) views self-regulation and self-cultivation as a process in which people are engaged in selective and self-regulatory activities making intentional efforts to achieve or maintain personally valued developmental states or outcomes. It is also a process aimed towards harmonizing personal goals (Gestsdottir and Lerner, 2008), managing life events that leads to qualitative changes of a personality (Shchukina, 2018). Taking into account the complexity of intentional self-development process, we consider it from two viewpoints: the first point indicates motivation and other personal characteristics as significant inner factors of initiation and regulation of selfdevelopment; the second point indicates a person's activity as goal-oriented actions in self-development.

\subsection{Inner Factors of Self-Development}

One of the key points in the concept of self-development is the inner factors promoting the efficacy of self-development. Growth goals and intrinsic motivation play major role in self-development (Bauer and McAdams, 2004). Nizovskikh (2008) described a variety of motives for self-development like imitation, need in love, recognition, self - cognition, self - understanding, self - affirmation, self-improvement, self - ful-fillment, etc. Dimensions of identity formation, goal effort, and mastery goal orientations accentuate motives for self-development and selfimprovement (Flunger et al. 2016). Selfdevelopment and its components correlate with not only motivation but with various personal characteristics. Ito and Kodama (2016) found out that sense of authenticity increased all kinds of intentional self-development (autonomy, self-cultivating motivation, and self-improvement motivation); contingent self-esteem increased self-improvement motivation. Brandtstädter (1999) states that reflective thought, intentional control of behaviors and goal achievement strategies are central processes that help create the desired change in behavior.

Considering self-development activity of a person (external and internal) plays a major role in it. According to Pappas and Pappas (2011) individuals in the process of selfdevelopment need to create a workable plan to be executed over a pre-determined period of time, to monitor progress, to reflect upon and evaluate progress, and to adjust the plan according to the relative successes or failures of the plan. The subjective interpretations of goals, self, actions including interpretations of one's own past and future are key to the process of intentional self-development (Bauer, 2009). In general, we may state that a person is an active agent in his or her own development. Self-development initiation and performance are enhanced by growth goals, intrinsic motivation, reflexivity, sense of authenticity, creation of a life plan, self-understanding, and interpretations of one's own actions.

\subsection{Life course Conception as Self-Development Factor}

As mentioned above, self-development is based on a person's self-awareness, interpretation of one's life priorities, goals, time perspective, i.e. person's numerous subjective ideas about one's whole life or conception of the life course. Life course conception reflects the most significant moments or events, which are connected to a person's main life purposes (Karpinsky, 2002). The notion of "life course conception" as person's ideas about their own lives is not sufficiently studied. Two overlapping scientific fields - life course sociology and lifespan developmental psychology focus on individual development and its factors (Diewald and Mayer, 2009). Authors of sociological and psychological works use the term "life course perspective" or "life course approach" which considers life events, person's roles and person's development from the date of birth till the date of death historically and socioeconomically (Crosnoe and Elder, 2015). Unlike "life course perspective" the notion of "life course conception" does not give objective description of life events but it gives mental representations of life course and subjective aspects of life perception. These subjective aspects of life perception as well as objective life events could be considered as factors influencing individual's behavior and development (Karpinsky, 2002).

The ideas about life course denote several patterns of life time (what happened in the past, the current situation, and future perspectives), based on personal values, beliefs, interests, intention, life orientations and life events (Lyz and Prima, 2009). We consider the subjective life course conception in two dimensions: temporal (ideas about 
life periods - the past, present, future time perspective) and composed (cognitive, emotional, and semantic components). Cognitive component includes attitude to life events, awareness of interrelation between those events, understanding the originality of one's own life, anticipation, and planning of the future life. Emotional component reflects emotional aspects of person's ideas about life. Semantic component includes person's consideration about life events and future life plans from the point of view of the significance (as a motivational factor) of those events and plans (Prima, 2011). We suggest that a person's life course conception is closely interrelated with the aspects of selfdevelopment. Thereafter we suppose that the improvement of student's life conception and formation of meaningful ideas about their own life are able to actualize self-development.

Based on this theoretical framework, we investigated two research questions:

- What is the role of subjective life course conception in students' self-development? What are peculiarities in self-development of students with mature and diffuse life course conception?

- Is it possible to enhance selfdevelopment of engineering students improving their life course conception?

\section{MATERIALS AND METHODS}

Two hundred and fifteen participants, 153 male and 62 female, aged from 17 to 22 (average 18,5), took part in the study. All participants are students of the Institute of Computer Technologies and Information Security studying Engineering (Information Technologies in particular).

Since the life course and selfdevelopment concepts are complex and not sufficiently and conclusively studied, an empiric research was carried out in three steps, as follows:

- single out components and indicators (primary and integrated) on the basis of theoretical analyses of life course conception and self-development;

- select measures, develop and test appropriate questionnaires to diagnose those components and indicators;

- state and validate assessment criteria for integrated indicators (high, middle, and low levels).

The key points and indicators in studying intentional self-development were:
- readiness for self-development (goal orientation in self-development, selfregulation skills);

- significance of self-development (values and semantic bases of the attitude to self-development, importance and the degree of priority of self-development among other spheres of life);

- activity in the process of selfdevelopment (professional skills development, improving communication style, widening one's cultural outlook, knowledge digestion, planning development, anticipating and overcoming difficulties);

- reflection on self-development (tendency to be self-aware, seeking a feedback to one's activity, awareness of other people influence on one's development, analysis of one's own feelings and experiences, assessment of one's own improvement);

- intrinsic motivation of selfdevelopment (intention to become a highskilled professional, to widen one's life perspectives and goals, to get rid of one's own deficiencies, and to gain moral and physical perfection);

- self-development incentives (interest towards the future profession, desire to gain reputation, to be the first in his/her group, to get a reward for one's activity, to widen one's life perspectives and goals, to get rid of one's own deficiencies, to avoid any criticism from others, intention to gain approval of or to get to the same level as their team members, sense of duty or obligation to people who matter, aspiration to live healthy lifestyle, fear of inevitable assessments and exams).

To assess self-development we used two specific tests called "Person's need of self-development" and "Integrative test of self-improvement in a professional field" (Istratova and Eksakusto, 2010) and a special questionnaire titled "Activity in selfdevelopment" (Prima, 2011). The "Person's need in self-development" test is formed as Likert scale and diagnoses personal attitude towards self-development (importance, necessity, and possibility). The "Integrative test of self-improvement in professional field" evaluates personal intention (inner motivation), self-development incentives, and activity in self-development process. The "Activity in self-development" questionnaire determines self-development skills, reflection, and control in self-development process due to the subjective assessment of the respondents. The questions in the questionnaire were about the directions in which participants 
are working on them-selves, factors that motivate them to engage in self-development and difficulties that they face on the way of changing themselves.

In studying life course conception three key components (semantic, emotional, and cognitive) formed the bedrock of it. The semantic component of life course conception was measured by Goal Orientation Test (Leontyev, 1993), Motivation Induction Method (Nuttin, 1985). Test of Goal Orientation is an adapted version of Purposein-Life Test (Crumbaugh and Maholick, 1964). On the basis of factor analyses five sub-scales are pointed out. They reflect three major existential orientations (past, present, and future) and two aspects of locus control (Leontyev, 1993). Motivation Induction Method is a measure of unaccomplished sentences. It helps diagnose motivational objects on the bases of person's intentions, ideas, anxieties which he or she puts in words. In our research this method was employed to find out respondents' dominant spheres of life activity by means of content analyses.

The emotional component was assessed by Time Orientations Scale (Nuttin, 1985). This scale diagnoses individual's attitudes towards the past, the present and the future. Cognitive component was measured by a specific questionnaire, which contained instructions and questions narrowed towards the life course conception and expected responses in a free form of a short essay (Prima, 2011). The questionnaire consists of 12 questions and implies both - free answers and optional answers. The questions were about the past (e.g. list significant past events, due to what factors those events happened and describe the way they influenced your life), the present (e.g. which life goals are the most important for you in the present time) and the future (e.g. describe future steps which you will do to achieve future goals). Focusing on our goal, we arranged the questions in such a way that the answers could reflect the student's ideas regarding of how their life events linked within the past and present / future. We were also interested in the comparability of the results with the scales of other methods used.

The indicators of the life course conception are:

- consistency of thelifecourseconception (an integrity of cognitive component of the life course conception, understanding of the life-time process in general and life events in their interrelation);

- perception of significant past achievements (past achievements which made an impact on other life events);

- attitude to oneself as a source of life events and achievements (internal locus of control);

- extension of future time perspective (certain period of time which is needed to fulfil plans, long-term perspectives);

- ideas in details (how detailed theseideas can be, life plans and awareness of completing certain actions for their implementation);

- effectiveness of life course ideas (the presence of definite life sense and relevance of life plans to it);

- balance of life course ideas (the consistency of life plans with dominant spheres of life activity)

In analyzing the life course conception our aim was to avoid evaluating the content of events, goals, plans, etc. but rather estimate the degree of maturity, consistency, detailing by means of the above-mentioned indicators. To that end some initial data was compared and assessed due to special criteria. For example, dealing with the 'balance of life course ideas' indicator an expert compared respondent's life plans (which were written in the questionnaire) with the dominant life spheres (which were revealed by means of Motivation Induction Method). We determined the level of intensity of this indicator (high, medium, low) on the basis of formalized criteria (Prima, 2011). The initial results on self-development and the life course conception based on the abovementioned measures were transformed into a data matrix comprising 72 primary and 13 integrated indicators of studied parameters for each respondent $(n=215)$.

The empirical research included two definite phases (Phase 1 and Phase 2). The main purpose of the First Phase was to examine if there was coherence of two analyzed constructs - the life course conception and intentional self-development. The constructs were so complicated and the importance of their characteristics both quantitative and qualitative, was so high that we took an indirect approach using the method of contrasting groups to determine their relationship. To validate the research the data was analyzed in two ways: first, we searched for the differences in indicators of self-development among students who had different levels of the life course conception (maturity and diffuse levels) (Phase 1.1); second, we studied the differences in the life course conception among students with different attitude to selfdevelopment like goal-oriented or spontaneous 
(Phase 1.2). F-distribution was used to define the differences statistically. In Phase 2 we implemented the "Life course conception" programme dedicated to improvement of students' life course conception and simultaneously, we studied changes in indicators of self-development as well as of the life course conception. Fifty students (33 male, 17 female) agreed to take part in this programme. Those respondents had mainly middle level of integrated indicators of selfdevelopment and the life course conception. Fifty of the same gender students were in the control group. There were no valid differences in studying indicators between the samples. The statistical analysis of data was made twice: once before and once after completion of the programme. The calculation of T-Wilcoxon test was used to rate the intensity of data shift - the direction and severity of available changes.

The "Life courseconception" programme included student group sessions, individual work, and group training. It took 18 weeks to complete the 36-hour course. The main topics of the course were: my opportunities, the others and I, my past, my present, my life goals, professional carrier, the way into the future. We used educational and psychological methods for the reflexive activity; students' work on their life plans and ideas of the life course (past, present and future); help in goal orientation and life plans detailing. In order to enhance engineering students' self-awareness psychometric tests (personal questionnaires) and some elements of psychological training (games and exercises on inter perception, leadership, and interaction) were used. It helped students to clarify and perceive their personal and professional characteristics. Understanding of social requirements in the contemporary world and professional skills was improved in discussions. By means of written reflections (essays) students analyzed their experience, understood their meaningful achievements, needs, intentions and life goals. To find causal connection linking life events and to create their own time perspective the students designed and implemented a special project. This project also helped the students to see themselves as managers of their own lives. In addition, the group session provided a forum for mutual exchange of participants' experiences.

\section{RESULTS}

During Phase 1 the data of the whole group was overviewed to mark two contrasting groups of students with mature and diffuse life course conception $(\mathrm{n} 1=35, \mathrm{n} 2=45)$. The first group consisted of students with high and middle levels of integrated indicators. The second group consisted of students with low and middle levels of integrated indicators. The results of the rest of respondents were excluded from the analysis at this stage. The conception of life course of the first group students could be described as consistent, holistic, effective, detailed, balanced, and meaningful; students of this group realized the importance of their own life achievements, considered themselves as the main source of life events. Life course conception of the second group (with diffuse ideas) carried the following characteristics: the system of life ideas was less organized; the level of experience awareness was low; the lack of life goal orientation; uncertainty of person's activity to achieve goals; the mismatch of life goals and priorities in life spheres.

Comparative analysis of intentional self-development between students with mature (group 1) and diffuse (group 2) life course ideas using F-distribution was made. The indicators which showed statistical significant differences are presented in [Table 1] below. 
Table 1. Indicators of self-development for students with mature and diffuse life course conception

\begin{tabular}{|c|c|c|c|}
\hline \multirow{2}{*}{$\begin{array}{l}\text { Self-der:elopwert } \\
\text { indicatars }\end{array}$} & \multicolumn{2}{|c|}{$\begin{array}{c}\text { Percentage } \\
\text { indication (\%) }\end{array}$} & \multirow{2}{*}{ F-digtrib. } \\
\hline & $\begin{array}{c}\text { स्माप्य } \\
1\end{array}$ & $\begin{array}{c}\text { 표표 } \\
2 \\
\end{array}$ & \\
\hline 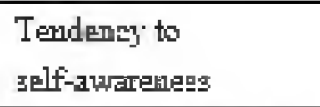 & 37.1 & 4.4 & $\begin{array}{l}q^{*}=3.87 \overline{3} \\
\mathrm{p}=0.013\end{array}$ \\
\hline $\begin{array}{l}\text { Seabine a foedback to } \\
\text { me"s action }\end{array}$ & 400 & 11.1 & $\begin{array}{l}\mathrm{T}^{*}=2.101 \\
4=0.011\end{array}$ \\
\hline $\begin{array}{l}\text { Ahwrireness of other } \\
\text { people wfluence on } \\
\text { sue's dev'elognent }\end{array}$ & 37.1 & 15.6 & $\begin{array}{l}\Phi^{*}=1.25 \overline{3} \\
P=0.05\rangle\end{array}$ \\
\hline $\begin{array}{l}\text { Integtion to become a } \\
\text { bighly; xbl]ed profea- } \\
\text { sinua] }\end{array}$ & 34.3 & 13.3 & $\begin{array}{l}\Psi^{*}=1.925 \\
F=0.05\end{array}$ \\
\hline 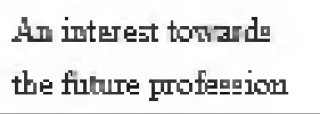 & 51.4 & 33.3 & $\begin{array}{l}q^{k}=1.035 \\
p=0.05\end{array}$ \\
\hline $\begin{array}{l}\text { Intention to eain good } \\
\text { Ieputation }\end{array}$ & 43.6 & 24.4 & $\begin{array}{l}q^{*}=2.483 \\
\{00.01\}\end{array}$ \\
\hline $\begin{array}{l}\text { Intention to be at the } \\
\text { top }\end{array}$ & 62.9 & 28.9 & $\begin{array}{l}\Phi^{*}=4.95 \overline{5} \\
(p \leq 0,01)\end{array}$ \\
\hline $\begin{array}{l}\text { Intention to get a re- } \\
\text { ward for oun's act:- } \\
\text { ity' }\end{array}$ & 34.3 & 13.6 & $\begin{array}{l}9^{:}=1.655 \\
P=05\end{array}$ \\
\hline $\begin{array}{l}\text { Intention to mider } \\
\text { aud"s life perspectives } \\
\text { and Ecald }\end{array}$ & 42.9 & 28.9 & $\begin{array}{l}\Psi^{*}=1.969 \\
p_{10} 05\end{array}$ \\
\hline $\begin{array}{l}\text { Intention to get rjid of } \\
\text { one's gnh defoler- } \\
\text { cien }\end{array}$ & 543 & 40.0 & $\begin{array}{l}\Psi^{*}=2.706 \\
F \rightarrow 01\end{array}$ \\
\hline 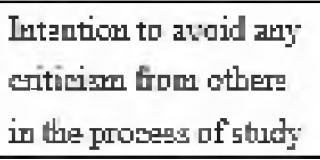 & 22.9 & 40.0 & $\begin{array}{l}\Psi^{*}=1.655 \\
p=0.05\end{array}$ \\
\hline 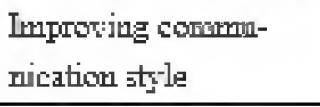 & 400 & 600 & $\begin{array}{l}\Psi^{*}=2.239 \\
\mathrm{~F}=013\end{array}$ \\
\hline $\begin{array}{l}\text { "hideming ane's cul- } \\
\text { twal gutlook }\end{array}$ & 22.9 & 33.3 & $\begin{array}{l}\Psi^{*}=1.689 \\
\mathrm{p}=0.05\end{array}$ \\
\hline
\end{tabular}

other people influence on one's development) is more common for students with mature life course conception, rather than to those, whose life ideas are diffuse;

- students with mature life course conception more often have inner motives to self-development (interest towards future profession, intention to become a highly skilled professional and to widen one's life perspectives and goals);

- students with mature life course conception usually have competitive motives: in comparison with the other group they have a better defined intention to gain good reputation and take the first place among others;

- one of the most valuable rewards for students with mature life course conception is approval from others, praise, financial incentives (students of this group are oriented not only towards their personal growth, but also towards other profits and benefits);

- the number of students with mature life course conception who are oriented to get rid of their own deficiencies is higher than the number of students from the other group;

- students with diffuse life course ideas tend to study mostly with a sense of duty or obligation to people who matter trying to avoid criticism;

- according to self-development activity, students with diffuse life course ideas tend to study in the sphere of culture, communication and cooperation with others.

After completion of Phase 1.1 we formed two new contrasting groups out of the whole number of participants. The first group included students with goal-oriented self-development, the second group included students, whose self-development was spontaneous (without any valuable inner reflection or process control) $(\mathrm{n} 1=34, \mathrm{n} 2=29)$. These groups have verified differences in the majority of studied indicators: readiness for self-development, activity in self-development, reflection of selfdevelopment, and intrinsic motivation.

Results describing the life course conception for students with goal-oriented and spontaneous self-development are shown in [Table 2] below.

The differences from Table 1 indicate the following characteristics of students:

- the number of students showing significance of self-awareness is higher in the group with mature life course conception than in the other group;

- reflection on self-development(seeking a feedback to one's activity, awareness of 
Table 2. Indicators of the life course conception for students with goal-oriented and spontaneous self-development

\begin{tabular}{|c|c|c|c|c|c|c|}
\hline \multirow{3}{*}{ Indicator of the life course conception } & \multicolumn{3}{|c|}{$\begin{array}{c}\text { Goal-oriented } \\
\text { self-development }\end{array}$} & \multicolumn{3}{|c|}{$\begin{array}{l}\text { Spontaneous } \\
\text { self-development }\end{array}$} \\
\hline & \multicolumn{6}{|c|}{ Percentage indication (\%) } \\
\hline & High 1w1 & Mid $1 \mathrm{v} 1$ & Low 1ø1 & High 1v1 & Mid lyl & Low $\mathrm{k} 1$ \\
\hline 1. Consistency of the life course conception & 20.6 & 17.6 & 61.8 & 6.9 & 13.8 & 79.3 \\
\hline 2. Perception of significant past achievements & 23.5 & 23.5 & 52.9 & 44.8 & 27.6 & 27.6 \\
\hline $\begin{array}{l}\text { 3. Attitude to oneself as a source of life events and } \\
\text { achievernents }\end{array}$ & 559 & 26.5 & 17.6 & 31.0 & 24.1 & 44.8 \\
\hline 4. Extension of future time perspective & 11.8 & 55.9 & 32.4 & 20.7 & 37.9 & 41.4 \\
\hline 5. Ideas in details (how detailed they are) & 47.1 & 17.6 & 35.3 & 27.6 & 10.3 & 62.1 \\
\hline 6. Effectiveness of life course ideas & 61.8 & 20.6 & 17.6 & 31.0 & 34.5 & 34.5 \\
\hline 7. Balance of life course ideas & 52.9 & 20.6 & 26.5 & 31.0 & 20.7 & 48.3 \\
\hline
\end{tabular}

The comparative analysis of the life course conception made in two groups revealed the following significant differences:

- the significance of past achievements is higher to the students with spontaneous selfdevelopment $\left(\varphi^{*}=4.525, \mathrm{p} \leq 0.01\right)$;

- the life course conception of students with spontanenus self-development is mostly less detailed $\left(\varphi^{*}=4.264, p \leq 0.01\right)$, than in the other group; there is a mismatch in goals and future plans of students with spontaneous selfdevelopment;

- the majority of students with goaloriented self-development can be characterized as a groun with high effectiveness of life course ideas $\left(\varphi^{*}=5.084, \mathrm{p} \leq 0.01\right)$. Unlike participants from the other group (with spontaneous selfdevelopment), they mostly have a certain life sense which causes rather meaningful life plans;

- the number of students with goaloriented self-development who have balanced life course ideas is higher than the number of the students with spontaneous selfdevelopment $\left(\varphi^{*}=4.371, \mathrm{p} \leq 0.01\right)$.

In Phase 2 the above-mentioned indicators of self-development and the life course conception were studied twice: once before commencement of the "Life course conception" programme and once after its completion. The results of the study of student's life course conception revealed positive trend in a large number of studied indicators, such as the perception of significant past achievements $(\mathrm{T}=10, \mathrm{p} \leq 0.01)$, attitude to oneself as a source of life events and achievements $(T=24.5, p \leq 0.01)$, extension of future time perspective $(\mathrm{T}=11, \mathrm{p} \leq 0.01)$, ideas in details $(T=8, p \leq 0.01)$, balance of life course ideas $(T=6, p \leq 0.01)$ and consistency of the life course conception $(\mathrm{T}=8.5, \mathrm{p} \leq 0.01)$. Moreover, we pointed out an increased level of integral indicators of self-development: significance of self-development ( $\mathrm{T}=5.5, \mathrm{p} \leq 0.01)$; activity in self-development process $(\mathrm{T}=24.0$, $\mathrm{p} \leq 0.01)$; reflection of self-development $(\mathrm{T}=28.5, \mathrm{p} \leq 0.01)$; intrinsic motivation of selfdevelopment $(T=30.0, p \leq 0.01)$; readiness for self-development $(T=7.5, p \leq 0.01)$. In the control group statistically valid differences were found out in only one indicator: reflection of self-development $(\mathrm{T}=7.4, \mathrm{p} \leq 0.01)$.

\section{DISCUSSIONS}

According to the results obtained by research student's self-development can be characterized as following: students with the mature life course concept in comparison with those, whose life ideas are diffuse, show intention towards self-reflection and selfawareness, and desire to improve them-selves. It is suggested that self-awareness promotes a holistic view on the life course and future perspectives, which in its turn enhances intention to self-develop. Students with the mature life course conception are more likely to have an intention to become highly skilled professionals, an intention to widen their life perspectives and goals, an intention to secure leadership position, and have interest in their professional future. However, their activity in self-development is initiated not only by internal, but also by external motives related to search of different benefits, a need for 
approval or reward (either moral or material), and competition with other group members.

Self-development of students with the diffuse life course conception is mostly initiated by external causes related to social environment and significant others, such as intention to avoid criticism and sense of duty. These students are likely to entrust their life course choice and decision-making activity to others. They are engaged in cultural development activity and improvement of their outlook and communication style in the process of self-development. According to these facts we may assume that these students are not able to identify their essential vector of self-development, because they lack significant life goals and they are not fully aware of their lives' perspectives.

Those students who are aware of the importance of self-development and have intrinsic motivation are more likely to believe in their own ability to manage their life events. Life course conception of students with goaloriented self-development is more detailed, effective, and balanced. This means that the existence of long term plans and awareness of actions that will bring them about are correlated. These students are more likely to self-develop according to their life aspirations, needs and intentions. They have a definite sense of their future and the relevance of their plans, and of consistency of their life plans with dominant spheres of their life activity. We conjecture that this holistic life course conception along with definite life goals enhances intention and creation of self-development programme. Students who understand the importance of self-development and have an intrinsic motivation are more likely to appreciate life opportunities, they are prone to see future perspectives and estimate the present as an important period of life. The students with spontaneous self-development give more significance to past achievements. That means that they highly evaluate their past efforts and achievements but are not yet ready to set their self-development goals. Whereas, people with goal-oriented self-development, tend to devalue their past efforts and achievements (possibly it may occur due to definitely planned future in detail).

The results of Phase 1 show that a small percentage of engineering students in the whole sample group has a high maturity level of the life course conception and goaloriented self-development ( $16.3 \%$ and $15.8 \%$, respectively). The ideas of life course are considered to be flexible and amenable to purposeful development. That is why the life course conception was chosen as an object of pedagogical influence. The idea of the life course conception improvement and students' self-development enhancement was studied by means of the "Life course Conception" programme. The results showed that students' conception of life course became more consistent, balanced and detailed. Having accomplished the programme the students, on the one hand, paid more attention to themselves as a source of life events, to significant past achievements and future plans, and, on the other hand, intensified self-development in the following categories: significance, activity, reflection, inner motivation and readiness for self-development. Taking into account the fact that self-development was influenced indirectly (by the program that improves the life course conception) the effect can be seen as positive.

Gained results affirm the idea that selfdevelopment initiation and performance are enhanced by growth goals cohered with the life goals, intrinsic motivation, reflexivity, creation of a life plan, and one's own relevant actions (Bauer and McAdams, 2004; Bauer, 2009; Pappas and Pappas, 2011). The study confirms that the subjective life course conception plays a great role in self-development of engineering students and by improving it self-development can be enhanced.

\section{CONCLUSIONS}

This research has "an investigative" character and therefore has some limitations. Firstly, the sample group size is not very big. Secondly, we used questionnaires based on the subjective opinions of students and indirect approach to the study of relationship between self-development and the life course conception. Nevertheless, reliability of the results and validity of the findings are proved by triple analysis: comparing contrast groups with different the life course conception; comparing contrast groups with different self-development; and checking changes in self-development in the situations when the life course conception was influenced. This research does not show strong characteristics of relationship between self-development and the life course conception. However, the results obtained give us an idea what to do further and allow us to draw the following conclusions.

The maturity of a student's life course 
conception, their awareness of experience and future goals, understanding of significant life achievements, attitude to oneself as a source of life events and achievements (internal locus of control), and thoughtful actions in goal pursuit promote a readiness for self-development, intrinsic motivation, and activity in selfdevelopment. Thus, the main role of life course conception is to actualize intrinsic motivation that makes self-development personally meaningful and goal-oriented. In other words, intention to self-development appears in case when a person has significant life goals and perspec-tives which may be reached through self-transformation.

To actualize students' self-development, we implemented the "Life course conception" programme which purposefully extended life course ideas and helped making those ideas integrate. We used educational and psychological methods providing reflexive activity; students' work on their life plans and ideas of life course (past, present, and future); self-awareness, goal orientation and life plans detailing. Due to this programme the students improved not only the life course conception but self-development either. It is extremely important to engineer-ing students because they often show the lack of interpersonal and intrapersonal skills. According to Alpay and Ireson (2006) opportunities to re-address any fixed (limiting) self-beliefs of engineering students may improve the efficacy of any subsequent skills training programme. That is why we presume that improvement of life course conception enhances students' selfdevelopment as well as further professional skills training.

One of the prospective questions that needs to be addressed is how to develop nontechnical skills in technical students? These skills have an inherent complexity and are difficult to pass with traditional means, which makes it complicated to learn as well as to teach them (Emilsson and Lilje, 2008). There is a certain experience in dealing with this problem, i.e. there are special psychological courses in engineering programmes, for example, "Higher Order Thinking in Science and Technology" (Pappas and Pappas, 2011), "Psychology for Engineers" (Alpay and Ireson, 2006). Our approach is also based on referring to a psychological course, involving reflective, psycho-diagnostic, and training methods. Teaching was based upon principles of person-centered education. It means that students' individuality, interests and purposes were taken into account, and the processes of their self-awareness and self-determination were supported to widen new opportunities in personal and professional self-development. The results of the study can be implemented in development of engineering programmes' using appropriate methods for facilitation of students' self-development.

\section{ACKNOWLEDGEMENTS}

The research was financially supported by the Southern Federal University.

\section{Conflict of interests} interest.

The authors declare no conflict of

\section{REFERENCES}

Abul'Khanova-Slavskaya, K.A. (1991). Стратегия жизни [Strategiya Zhizni]. Москва: Мысль. Retrieved October 25, 2019, from http:// rubinstein-society.ru/cntnt/nauchnie-raboti/ raboti-k-a-abulh/strategiya.html

Alpay, E., \& Ireson, J. (2006). Self-theories of intelligence of engineering students. European Journal of Engineering Education, 31(2), 169-180. https://doi.org/10.1080/03043790600567027

Bauer, J. J. (2009). Intentional self-development. In J. Lopez (Ed.), The Encyclopedia of positive psychology (pp. 523-527). Malden: Wiley-Blackwell. https://doi. org/10.1002/9781444306002.ch9

Bauer, J. J., \& McAdams, D. P. (2004). Growth goals, maturity, and well-being. Developmental Psy-chology, 40(1), 114-127. https://doi. org/10.1037/0012-1649.40.1.114

Brandtstädter, J. (1999). The self in action and development:Cultural,biosocial, and ontogenetic bases of intentional self-development. In J. Brandtstädter \& R. M. Lerner, Action \& selfdevelopment: Theory and research through the life span (pp. 37-65). Sage Publi-cations, Inc. https://doi.org/10.4135/9781452204802.n2

Brandtstädter, J. (2009). Goal pursuit and goal adjustment: self-regulation and intentional self-development in changing developmental contexts. Advances in Life Course Research, $14(1-2), \quad 52-62 . \quad \mathrm{https} / / /$ doi.org/10.1016/j. alcr. 2009.03 .002

Chickering, A. W., \& Reisser, L. (1993). Education and Identity ( ${ }^{\text {nd }}$ ed.). San Francisco: Jossey-Bass. Retrieved from ERIC database. (ED423498) https://eric.ed.gov/?id=ED423498

Crumbaugh, J. C., \& Maholick, L. T. (1964). An experimental study in existentialism: The psychometric approach to Frankl's concept of noogenic neurosis. Journal of ClinicalPsychology, 20(2), 200-207. https://doi.org/10.1002/1097$4679(196404) 20: 2<200:$ : A I D JCLP2270200203>3.0.CO;2-U

Crosnoe, R., \& Elder, G. H. (2015). Life Course: Sociological Aspects. In: J. D. Wright (Ed.), 
International Encyclopedia of the Social \& Behavioral Sciences (Second Edition) (pp. 80-84). Amsterdam: Elsevier. https://doi.org/10.1016/ B978-0-08-097086-8.34037-5

Diewald, M., \& Mayer, K.U. (2009). The sociology of the life course and life span psychology: Integrated paradigm or complementing pathways? Advances in Life Course Research, 14(1-2), 5-14. https://doi.org/10.1016/j. alcr.2009.03.001

Emilsson, U. M., \& Lilje, B. (2008). Training social competence in engineering education: necessary, possible or not even desirable? An explorative study from a surveying education programme. European Journal of Engineering Education, 33(3), 259-269. hitps://doi org/10.1080/03043790802088376

Flunger, B., Marttinen, E., Tuominen-Soini, H., \& Salmela-Aro, K. (2016). How do young adults orchestrate their multiple achievement-related goals? Associations of achievement goal orientations with identity formation and goal appraisals. Research in Human Development, 13(4), 342-362. https://doi.org/10.1080/154276 09.2016.1234309

Gestsdottir, S., \& Lerner, R. M. (2008). Positive development in adolescence: The development and role of intentional self-regulation. Human Development, 51(3), 202-224. https://doi. org/10.1159/000135757

Istratova, O. N., \& Eksakusto, T. V. (2010). Справочник психолога-консультанта организауии (3-е издание) [Handbook of the Psychologist Consultant of the Organization $\left(3^{\text {th }}\right.$ ed.)]. Ростов-на-Дону: Феникс. https://elibrary.ru/ item.asp?id $=20105686$

Ito, M., \& Kodama, M. (2006). Self-feelings that support intentional self-development in university students: sense of authenticity and global and contingent self-esteem. Japanese Journal of Educational Psychology, 54(2), 222232. https://doi.org/10.5926/jjep1953.54.2_222

Karpinsky, K.V. (2002). Человек как субъект жизни [A person as a subject of life]. Гродно: Издво ГрГУ. Retrieved September 28, 2018, from https://www.psyoffice.ru/3788-karpinskijj-k.v.chelovek-kak-subekt-zhizni..html

Kibal'chenko, I. A., \& Eksakusto, T. V. (2019). Modern students' mental representations of success. International Journal of Cognitive Research in Science, Engineering and Education (IJCRSEE), 7(1), 1-13. https://doi.org/10.5937/ ijcrsee $1901001 \mathrm{~K}$

Leontyev, D. A. (1993). Тест смысложсизненных ориентаций: Методическое руководство [Purpose-in-Life Test: Tutorial Materials]. Москва: Смысл. Retrieved September 3, 2017. from http://publishing.smysl.ru/book/sgo/ ManSGO.pdf

Lyz, N. A. (2012). The educational competence of college students as a factor of the quality of higher education. Russian Education and Society, 54(6), 80-95. https://doi.org/10.2753/ RES1060-9393540605

Lyz, N., \& Opryshko, A. (2016). Life-creating education: new educational meanings in modern world. On the Horizon, 24(4), 377-386. https:// doi.org/10.1108/OTH-06-2016-0028

Lyz, N. A., \& Poznina, N. А. (2010). Педагогические риски технизированных образовательных сред [Teaching risks of technicalized educational environment]. Pedagogics, 4, 33-42. https:// elibrary.ru/item.asp?id $=15175361$

Lyz, N. A., \& Prima, A. К. (2009). К проблеме изучения представлений о жизненном пути как характеристики субъекта жизни [То the problem of studying life course conception as an attribute of life subject]. In А.Л. Журавлев, В.А. Барабанщиков, \& М.И. Воловикова (Eds.), Психология человека в современном мире. (pp. 248-255). Москва: Изд-во «Институт психологии РАН». Retrieved September 28, 2018, from http://www.ipras.ru/engine/ documents/document2001.pdf

McCann, L. I., \& Pearlman, L. A. (1992). Constructivist self-development theory: A theoretical framework for assessing and treating traumatized college students. Journal of American College Health, 40(4), 189-196. https://doi.org/10.1080/ 07448481.1992 .9936281

Mirzagitova, A. L., \& Akhmetov, L. G. (2015). Selfdevelopment of pedagogical competence of future teacher. International Education Studies, 8(3), 114-121. https://doi.org/10.5539/ies. v8n3p114

Morf, C., \& Horvath, S. (2010). Self-Regulation pro-cesses and their signatures: Dynamics of the self-system. In R. Hoyle, Handbook of per-sonality and self-regulation (pp. 117144). Malden: Wiley-Blackwell. https://doi. org/10.1002/9781444318111.ch6

Nizovskikh, N. A. (2008). Мотивация саморазвития человека [Motivation of person's selfdevelopment]. Вестник Вятского государственного университета, 1(1), 113-120. Retrieved March 31, 2018, from https://cyberleninka.ru/article/n/motivatsiyasamorazvitiya-cheloveka

Nuttin, J. (Ed.). (1985). Future Time Perspective and Motivation: Theory and Research Method. Leuven: Univ. Pr.

Pappas, E., \& Pappas, J. (2011). Behavioral approach to building cognitive foundations for effective thought and action. Innovative Higher Education, 36(5), 359-372. https://doi.org/10.1007/s10755011-9178-8

Perez, T., Cromley, J., \& Kaplan, A. (2014). The role of identity development, values, and costs in college STEM retention. Journal of Educational Psychology, 106(1), 315-329. https://doi. org/10.1037/a0034027

Prima, А.К. (2011). Представления о жизненном пути в структуре субъектности студентов вуза [The life span conception as a part of inner activity structure of university students]. Нзвестия Южсого федерального университета. Педагогические науки, 4, 122-130. Retrieved March 31, 2018, from http://pedsciencemag.ddk. com.ru/bulletin/pdfVersion?articleIdd $=1023$

Rasoal, C., Danielsson, H., \& Jungert, T. (2012). Empathy among students in engineering programmes. European Journal of Engineering Education, 37(5), 427-435. https://doi.org/10.10 $80 / 03043797.2012 .708720$

Shchukina, M. A. (2018). Heuristics of the subject approach in the psychological consciousness of personal self-development. Psikhologicheskii Zhurnal, 39(2), 48-57. https://doi.org/10.7868/ S0205959218020058

Stiwne, E. E., \& Jungert, T. (2010). Engineering 
Lyz, N., Prima, A., Opryshko, A. (2020). The role of students' life course conception in their self-development, International Journal of Cognitive Research in Science, Engineering and Education (IJCRSEE), 8(1), 37-48

students' experiences of transition from study to work. Journal of Education and Work, 23(5), 417-437. https://doi.org/10.1080/13639080.201 0.515967

Yang, C. C., \& Brown, B. B. (2016). Online selfpresentation on Facebook and self development during the college transition. Journal of Youth and Adolescence, 45(2), 402-416. https://doi. org/10.1007/s10964-015-0385-y 